\begin{tabular}{|c|c|}
\hline \multirow{3}{*}{ 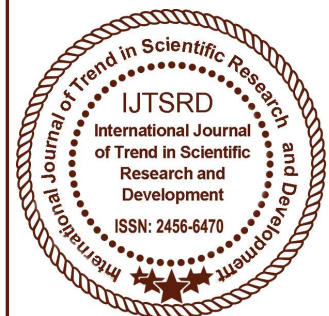 } & $\begin{array}{l}\text { International Journal of Trend in Scientific } \\
\text { Research and Development (IJTSRD) }\end{array}$ \\
\hline & International Open Access Journal \\
\hline & ISSN No: 2456 - 6470 | www.ijtsrd.com | Volume - 2 | Issue -4 \\
\hline
\end{tabular}

\title{
The Education and Compensation Factors Affect to the Performance
}

\author{
HD. Melva Sitanggang, Togu Harlen Lbn. Raja \\ University of Prima Indonesia, Sekolah Tinggi Ilmu Ekonomi LMII
}

\begin{abstract}
The organization is the collection of people who cooperate in achieving the objectives which people have different behavior in work and needed a good education that should be owned by the Organization so that all employees that is in these organizations contribute to produce a good performance for the organization.
\end{abstract}

In every organization has a strong influence on education to sustainability of the Organization for the future so that all organizations must have good planning to increase officers' education periodically.

Beside the education, then other factors that can affect the performance of the organization are the magnitude of the company's reward to the employees over the retribution of employees to the organization.

In providing compensation to any employee so that the Organization should perceive either about the system of granting compensation given to officers so there is competition among fellow officers in carrying out his work.

Keywords: education, compensation and performance

\section{INTRODUCTION}

Performance is the end result expected from a production process for any company and this performance is a very important goal for the company. One of the many other factors is education and compensation.

In the development of the business the company must keep its commitment in improving the quality of education for its employees so the company can exist during the time it could not be determined.
The leadership of the company always pays attention to the quality of its human resources in the works where the quality of the output of the company shall be retained by the company in keeping customer loyalty the company responsible for the product produced by the company where there is intense competition in the market is very tight.

Some effort is made by the company in improving the quality of its employees includes:

1. to increased formal education of the employees.

2. To increase informal education of the employees.

Education is increasingly high so that for this company is a serious response to be followed by the company by preparing all the potential companies to be able to follow the development of existing science.

Education continues to experience high development that cannot be hindered and we also cannot avoid the development of science so that the company must always be ready to accept the development of science.

Education is a process of changing human behavior over its environment and will create custom behaviors, thoughts and his attitude. (Hasibuan, 2007).

The rapid development of science must be followed by the leadership of the company by preparing the availability of labor to the company to answer the challenges of the times.

In any organization thus man is a motor mover all activities of the Organization in which all activities in the company held by humans. 
Human resources have huge influence over the development of the company where performance will be achieved by companies affected by the availability of the workforce at the company.

Companies should be able to prepare human resource planning well through the availability of labor both in quantity of labor quality in order to achieve corporate goals that have been predetermined so that companies avoid the loss.

The company should be always to prepare the fund in in the framework of human resource planning, procurement of human resources and maintenance of human resources as well as improvement of existing human resources education.

The ultimate goal of the company is how to achieve maximum output or productivity of the company so that the company will succeed to achieve big profits at the end of each year and the longer the company will grow.

The purpose of the company is a shared commitment between employees and companies in order to achieve high productivity based on the performance of employees as a whole for a certain period of time.

Large corporate productivity must be shared with the employees of the company through compensation given to each employee such as salaries, benefits and other facilities to be received by employees.

Leaders of the company must always pay attention to the future of the company for the future so that all factors that contribute to the development of the company should be thought by the leadership of the company so that company planning that has been prepared every year can be achieved.

In order to maintain or develop the company for the future, the company should strive to develop management so that it can adjust to the development of the company in the future.

Management development is the company's attitude to keep, maintain and improve employee performance with changing employee behavior with training programs and job rotation. (Gary Dessler, 1997).

One of the factors that are important to the company for the future of the company is the amount of the compensation given to the employee so that the employee who works will provide optimum performance in work at the company.

Large or small the granting of Compensation by the company to the employee will have an impact on the performance given by every employee at the company where the huge compensation will make employees work morale increasingly diligent and so Conversely when the company give small compensate then the employees will lose morale. Providing compensation by the company to employees should be done fairly for employees so that will create an atmosphere of work more conducive in the environment of the company with consideration of the work performance and quality of human resources. Company performance is the accumulation of all employee performance that exists in the company produced by every employee in working at one certain period of time and this is called with company performance.

Leaders of successful companies when the leadership is able to realize the performance of the company every year through the achievement of good performance by the company where the company is able to earn profits for the company at the end of the year.

The success of a leader when able to produce great performance for the company within a certain period of time through profits generated by the company each year.

\section{THE FORMULATION OF THE PROBLEMS}

The formulation of the problem of the problems obtained is as follows:

1. How much influence of education variables to performance variables.

2. How much influence the variable compensation to performance variables.

3. How much influence of education variables and compensation variables on performance.

\section{THE OBJECTIVE OF RESEARCH}

1. To find out how much influence of education on performance.

2. To find out how much influence the compensation on performance.

3. To find out how much influence the education and compensation for performance. 


\section{THE REVIEW OF LITERATURE}

\section{Education.}

Education is a way of improving the performance of the company so the existing employees should be upgraded their education every year to anticipate the development of science.

With the education owned by an employee explains that the employee's behavior will be directed to the goals expected in the company.

Napitupulu, 2001, in Vidya Ari Septiana, 2014, says that education is the result of science and the outcome of one's experience is structured logically systematically in order to change the attitudes of others.

The company must constantly upgrade its human resources through the improvement of education to its employees so that employee performance can be maintained and enhanced every year.

The level of education own by a person is an effort to increase one's competitiveness within the company and to improve the performance of the company. (Hariandja, 2002).

Sedarmayanti, 2010, said that high level of education will support the achievement of performance and low level of education will result in difficulty of employees in receiving the flow of information related to its activities.

Then Sutrisno, 2011, said that education is the overall attitude and human behavior that resulted through changes in behavior that occur on an ongoing basis.

\section{Compensation.}

When companies talk about compensation then the company is faced with a dilemma between efficiency with the work of the company, where the attitude of the company in general is how to spend the cost with efficiency so that gain big profits.

Compensation is a form of expenditure or cost that must be incurred by the company and the more compensation and type of compensation provided by the company the greater the total expenses of the company.
Handoko, 2008, said that compensation is a form of remuneration that employees receive on their performance.

Furthermore, Martoyo, 2000, said that compensation is a regular form and system for the remuneration received by employees of companies either in the form of money or non-money.

Giving a form of compensation from the company to employees should be given in a fair manner arranged by the company in the system of compensation so that it will be able to improve employee morale.

\section{Performance.}

Activities undertaken by employees is the result of performance generated by the performance of employees and employees who can contribute to the company at one time period.

Companies need to pay attention to the performance of their employees because the future sustainability of the company can be influenced employee performance, then the company leadership needs to make an assessment of employee performance.

Mangkunegara, 2000, gives the definition of performance is the output of employee performance at a certain period of time with the quality and quantity of employee productivity with good results.

Hasibuan, M., 2007, explains that performance can be measured from:

1. The loyalty of Employee to the company that is always ready to defend and raise the company.

2. Achievement of work is the achievement of quality and quantity of work by employees in the work every day.

3. Honesty is important for employees in performing their duties well to the company.

4. Discipline of employees in order to enforce the rules that exist in the company.

5. Employee creativity that is the ability of employees in developing their creativity in order to complete the task.

6. Cooperation is the attitude of employees to cooperate with other employees both within the environment and outside the environment.

7. Leadership is the ability of the leadership to influence his subordinates to work well.

8. Personality is the attitude and behavior of a person in carrying out its activities. 
9. The initiative is the original thinking ability and on its own initiative.

10. Skills is the ability to carrying out the work of employees.

11. Responsibility is the willingness of employees in carrying out their duties.

\section{THE PREVIOUS OF RESEARCH}

1. Dwi Indah Rosanti, 2014, explains the results of his research that education has an influence on performance at PT. Lati Prayogi where $\mathrm{t}$ arithmetic equal to 2,129>t table equal to 0,045 .

2. Futu Yogi Handika, 2016, explains the result of his research that the independent variable of compensation gives influence to the performance of Hotel Bakung Sari Kuta employees 0,002<0,05 then Ho is rejected and $\mathrm{H} 1$ accepted.

3. Oktavia Kontu, Peggy Mekel, Sileyljeova Moniharapaon, 2015, explains the results of his research that education has an influence on the performance where $\mathrm{T}$ count $>\mathrm{T}$ table is $2.523>$ 1.6973.

4. Aprizon, 2014, Explain that the results of his research variable compensation has a great influence on teacher performance where R2 of $52.1 \%$.

\section{CONCEPTUAL FRAMEWORK}
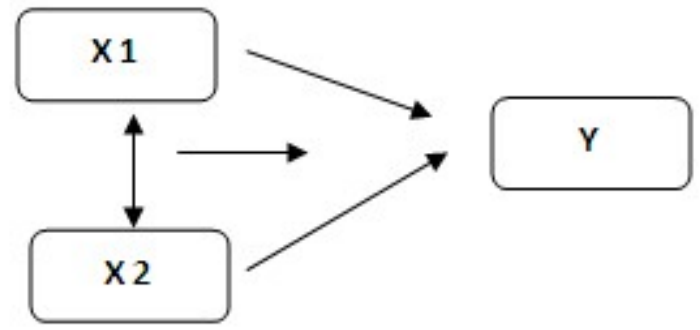

\section{Information:}

$\mathrm{X} 1=$ Education

$\mathrm{X} 2$ = Compensation

$\mathrm{Y}=$ Performance

\section{THE PREMISE}

In qualitative research where data has not direct data can be processed, but the data is still raw data collected through a research tool called the research instrument.

Therefore it is still difficult to make a hypothesis because the data has not quantitative data that can be directly processed using statistical methods, but with the help of theory, framework of thinking and previous research can be formed premise.
The premise is the basic logic that can be associated with the formation of hypotheses by connecting several variables used in the study.

\section{Premise 1}

Dwi Indah Rosanti, 2014, explains the results of his research that education has an influence on performance at PT. Lati Prayogi where $\mathrm{t}$ arithmetic equal to $2,129>\mathrm{t}$ table equal to 0,045 .

\section{Premise 2}

Futu Yogi Handika, 2016, explains the results of his research that the independent variables of compensation have an influence on the performance of Hotel Bakung Sari Kuta employees of $0.002<0.05$ then $\mathrm{Ho}$ is rejected and $\mathrm{H} 1$ accepted.

\section{Premise 3}

Oktavia Kontu, Peggy Mekel, Sileyljeova Moniharapaon, 2015, explains the results of his research that education has an influence on the performance where $\mathrm{T}$ counts $>\mathrm{T}$ table is 2.523> 1.6973.

\section{Premise 4}

Aprizon, 2014, explained that the result of his research variable compensation has a great influence on teacher performance where R2 is $52.1 \%$.

\section{The Hypothesis}

1. Suspected there is influence of education with performance.

2. Suspected there is influence of compensation with performance.

3. Allegedly there is an influence of education and compensation with performance.

\section{THE METHODOLOGY OG RESEARCH}

\section{The Type of Research}

This study is an associative study that asks for the relationship between one or more variables (Sugiono, 2007).

\section{The Place of Research.}

The place of research is Gotong Royong Mandiri Cooperative Office located at Jalan Lapangan Medan.

\section{Population and Sample}

Population in this research is all employees that exist in Cooperative Office of Gotong Royong Mandiri 
which amounts to 46 people so that this population also as sample of research.

\section{The Research Methods.}

Research data collected through data collection instrument that is obtained from all employees at Cooperative Gotong Royong Mandiri. Instruments such data include: observation, interviews, questionnaires and documentation.

\section{DISCUSSION}

\section{Effect of Education on Performance.}

Education is a requirement of human resources where education will change attitudes and human behavior to work better and goals together can be achieved.

Companies should make plans to improve education to their employees through formal and informal education (training, workshops, seminars, etc.) so that each employee has different skills and will be able to cope with obstacles when employees are unable to work.

Based on the results of data processing from education variables (X1) obtained $\mathrm{T}$. Calculate of 1.700 or $17 \%$ which means that education (X1) has an influence on the performance $(Y)$ of $17 \%$.

\section{Influence of Independent Variable (X1) Against} Variable Dependent Variable Performance (Y).

Then compensation (X2) also gives effect to the performance (Y) because with the award of compensation of interest given by company to employee hence can arouse employees spirit.

There are two forms of compensation:

1. The form of intrinsic compensation is a form of appreciation given by the company to employees for its services in the form of money such as: salaries, bonuses and allowances.

2. Extrinsic form of compensation is a form of corporate rewards to employees not in the form of money but in the form of: promotion, improvement of education, health assistance, housing assistance, etc.

Based on the data processing on the research data on the compensation variable (X2) obtained T. Calculate of 5.308 or $53.08 \%$ which means that the compensation variable (X2) has an effect on the performance $(\mathrm{Y})$ of $53.08 \%$.

\section{The Effect of Education and Compensation on Performance.}

Many factors can affect a person's performance in working with the company and these factors contribute differently to human performance.

From result of data processing obtained that independent variable of education and independent variable of compensation influence simultaneously to performance dependent variable $(\mathrm{Y})$ with value $\mathrm{F}$. Calculate equal to 16,079 or equal to $16,1 \%$ meaning there is still more about $83,9 \%$ again other factors that affect performance.

\section{CONCLUSION}

1. From the results of the study explained that the variables Education (X1) gives the influence to the performance variable (Y) of $17 \%$.

2. Then the compensation variable (X2) gives influence to the performance variable $(\mathrm{Y})$ of 53 , $08 \%$.

3. Together variables education (X1) and compensation variable (X2) has an effect on the performance variable of $16.1 \%$.

\section{SUGGESTION}

1. From the result of research of education variable (X1) give influence $17 \%$ where contribution from education have not maximal give influence to performance variable (Y), therefore suggested company should pay attention to level of employee education through improvement of formal education and informal education.

2. Variable compensation (X2) has an effect of $53.08 \%$ on the performance (Y) means that the company has given good compensation to employees, but still recommended that the company still pay compensation to employees so that employees can improve morale and improve performance.

\section{BIBLIOGRAPHY}

1. Dwi Indah Rosanti, 2014, Hubungan Pendidikan Dan Kompensasi Terhadap Kinerja PT. Lati Prayogi, Jurnal Ilmu Dan Riset Manajemen, Vol. 3 No. 11.

2. Futu Yogi Handika, 2016, Pengaruh Kompensasi Pendidikan dan Pelatihan Terhadap Kinerja Karyawan Pada Bakung Sari Hotel Kuta, E-Jurnal Manajemen Unud, Vol. 5, No. 5. 
3. Handoko, T. Hani, 2008, Manajemen, Edisi Kedua, Penerbit BPFE, Yogyakarta.

4. Hariandja, M.T.E., 2002, MSDM, Cetakan Pertama, Penerbit BPFE, Yogyakarta.

5. Hasibuan, M., 2009, MSDM (Edisi Revisi), Penerbit PT. Bumi Aksara, Jakarta.

6. Gary, Dessler, 1997, MSDM, Penerbit PT. Prenhallindo, Jakarta.

7. Mangkunegara, P., A., 2000, Manajemen Sumber Daya Manusia Perusahaan, Penerbit Rosdakarya, Bandung.
8. Martoyo, Susilo, 2000, MSDM, Edisi Keempat, Penerbit BPFE, Yogyakarta.

9. Oktavia Kontu, Peggy Mekel, Sileyljeova Moniharapaon, 2015, Hubungan Pendidikan dan Kompensasi Terhadap Kinerja Pegawai, Jurnal EMBA, Vol 3. No. 1 Maret 2015.

10. Sedarmayanti, 2010, MSDM Reformasi Birokrasi Pegawai Negeri Sipil, PT. Refika Aditama, Bandung.

11. Sugiyono, 2007, Statistika , Penerbit Alfabeta, Bandung

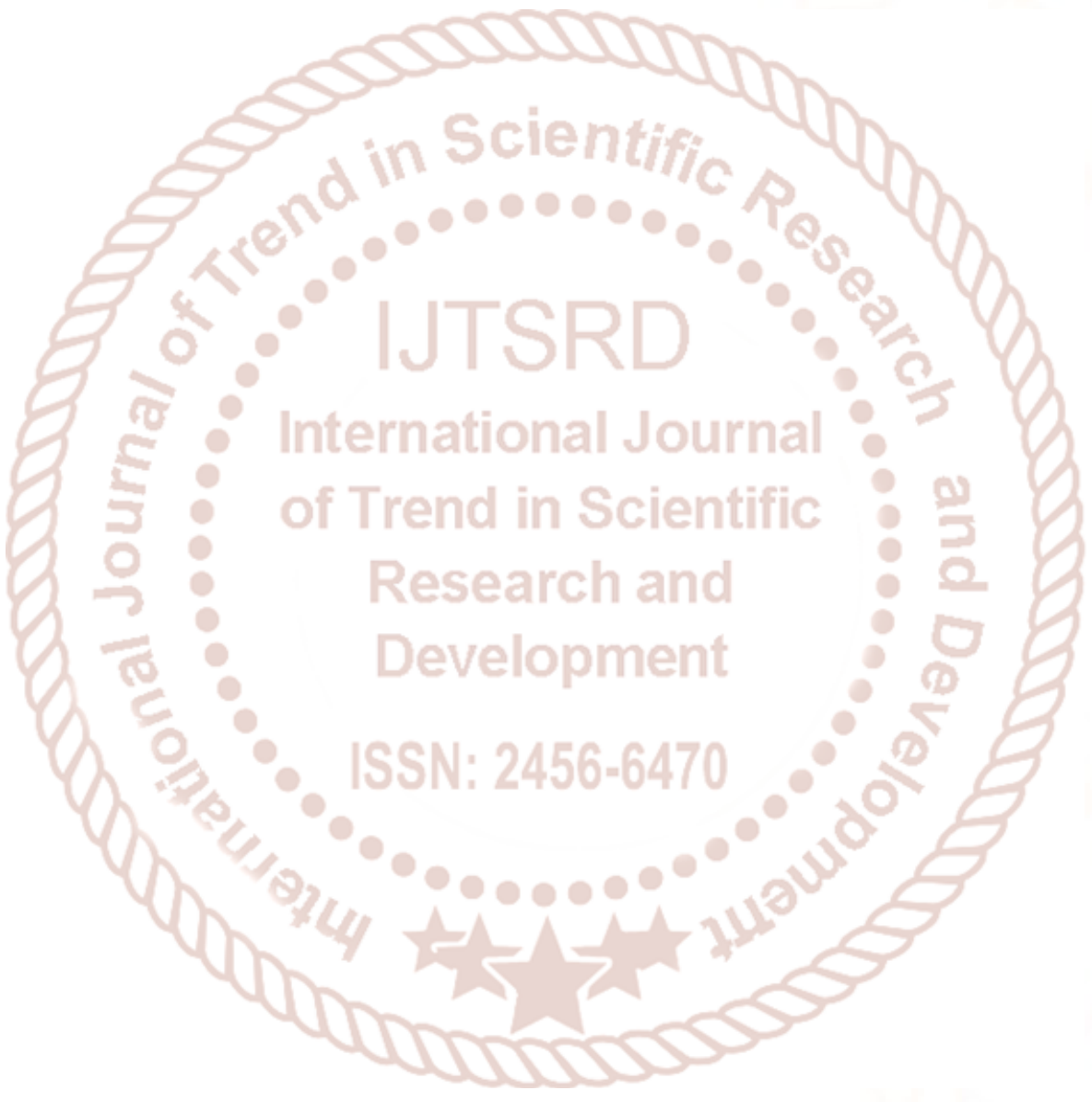

